Dr DAVID ROBIE is editor of Pacific Journalism Review and an environmental journalist.

\section{Timely climate media strategy to empower citizens}

Journalism and Climate Crisis: Public Engagement, Media Alternatives, edited by Robert A. Hackett, Susan Forde, Shane Gunster and Kerrie Foxwell-Norton. Abingdon, UK: Routledge. 2017. 204 pages. ISBN 9781-1389-5039-9

\section{A}

$\mathrm{T}$ THE time of reviewing this important and timely book, Hurricane Irma had just ripped a trail of unprecedented destruction from Antigua, Barbuda and Saint Barthélemy in the eastern Caribbean to Florida with at least 81 deaths.

Florida involved one of the largest mass evacuations in US history, with nearly 7 million people being warned to seek shelter elsewhere. Seventy per cent of Miami lost electricity at the height of the storm.

And Irma in turn had followed on the heels of Hurricane Harvey, which devastated a large swathe of Texas. This was the first major hurricane to hit US soil in more than a dozen years.

Seventy-one fatalities and more than US\$70 billion in damage. Two wrecking storms of such destructive force hitting the US mainland in less than a fortnight.

Unsurprisingly, President Donald Trump dismissed any link between

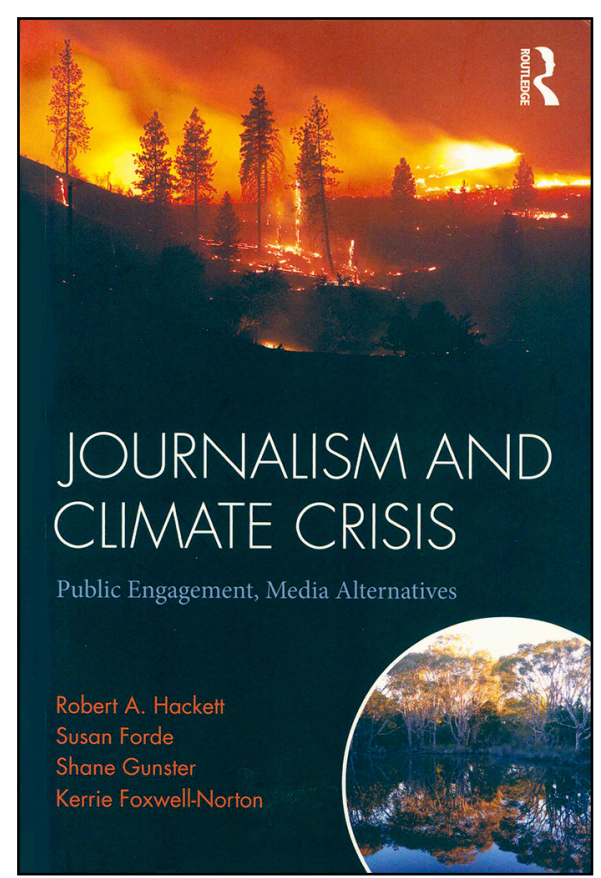

climate change and the two hurricanes. 'We've had bigger storms than this,' he snorted, even though earlier he had 'marvelled' at their historic size.

The catastrophic category 5 Hurricane Irma sparked an analysis of media responses by Carbon Brief and a forensic examination of the science of climate and Atlantic hurricanes. Citing three climate specialists in particular, the website concluded: 'The strongest hurricanes have gotten stronger because of global warming' (Multiple authors, 2017).

Florida's global warming denier governor Rick Scott weathered criticism after the devastation to his state by still refusing to say - as he has done for seven years since he was first elected in 2010-if he believes man-made climate change is real (Caputo, 2017). 
This is all rather ironic given that at the time of completing Journalism and Climate Crisis: Public Engagement, Media Alternatives, the co-authors were writing in the context of massive wildfire ravages in the Canadian city of Fort McMurray-epicentre of one of the world's most controversial energy mega-projects, the Alberta tar sands - and, on the other side of the globe, aggressive wildfires were savaging Australia with sharply increasing frequency and intensity.

Just a few years earlier, in 2009, 173 people had perished in the 'Black Saturday' bushfires that engulfed the community of Kinglake in the state of Victoria. Disturbing coral bleaching was also damaging Australia's popular tourist attraction Great Barrier Reef off the Queensland coast.

Noting that the reality of anthropogenic climate challenge can no longer be ignored, this book warns that neither can the 'responsibility of journalism to inform, motivate and empower citizens to engage with the problem' (p. 2)

Journalism and Climate Crisis seeks to disrupt the status quo of the way climate change is reported in much of the world, especially Anglo countries such as Australia, Canada, New Zealand and the United States, and to offer strategies for community empowerment, action and hope in the digital age.

While much of the mainstream media, compromised as they are through their declining commercial models, offer little scope for change, the co-authors offer many examples of active communication success, mostly through alternative media.

The four co-authors are uniquely qualified for this collaborative volume. Robert A. Hackett is professor of communication at Simon Fraser University, Vancouver, and as a co-founder of NewsWatch Canada, and has been a leading writer on environmental and peace journalism models. He also contributed an issue-defining article in the last edition of Pacific Journalism Review on climate change and critical media models.

Susan Forde is director of the Griffith Centre for Social and Cultural Research and associate professor of journalism at Griffith University, Australia, and whose books include Challenging the News on alternative media. Shane Gunster is a colleague of Hackett at Simon Fraser University, where he is an associate professor in the School of Communication. Kerrie Foxwell-Norton is senior lecturer in journalism and media studies at Griffith University and a co-author of Developing Dialogues.

The book is divided into seven chapters as well as an introduction to journalism models for climate crisis and a conclusion written by the co-authors. The first chapter is on Democracy, Climate Crisis and Journalism, looking at 'normative touchstones', followed by a chapter on Engaging Climate Communication, which examines audiences, frames, values and norms. The third chapter deals with Environmental Protest, Politics and Media Interactions.

Chapter four From Frames to Paradigms offers an in-depth comparative 
analysis of civic (or public) journalism, peace journalism and alternative media. This is followed by a British Columbia case study on Contesting Conflict with an examination of advocacy and alternative media in that province.

Chapter six analyses Australian independent news media and climate change in the context of COP21 when the historic Paris Agreement was forged. The final chapter looks at a Guardian Australia case study to demonstrate alternative approaches to environmental coverage. The conclusion offers a strategy for 'media reform for climate action'.

Writing about 'ordinary journalism in extraordinary times', the authors argue that the conglomerates that 'increasingly dominate media ownership are maximising short-term profits, stripping assets and disinvesting in news and thus have declining capacity and inclination to face up to the challenges of climate crisis.' Mirroring the arguments of McChesney and Nichols, for example, the authors state:

Working journalists are faced with tighter deadlines, heavier workloads, multiplatform demands, a 24/7 news hole to fill and a broader palette of topics to report. The result is predictable: fewer beat [rounds] reporters with specialised expertise, less investigative or accountability journalism, more pressure to act like stenographers, reporting competing claims rather than assessing their respective validity (p. 4).

However, the problem does not end there. It goes beyond the "crisis of jour- nalism's business model - Climate Crisis journalism faces aditional barriers of institutional structure, class power and ideology'. Citing Naomi Klein's argument for taking climate change seriously, they reaffirm the need for a positive role for government, a strengthened public sector and collective actionwhich is precisely why conservative political forces, especially in North America and Australia, prefer not to take it seriously.

The co-authors argue that journalism needs to rethink its mission to cover urgent political issues such as climate change. The problem is less about the informed citizen, and much more about empowering the public to be engaged. They are highly critical of how 'elite media' in Australia and the US, for example, have privileged denialist opinion and vested interests, blaming them for widespread misinformation and disengagement. This is contrasted with Western Europe's 'vibrant and pluralistic' media systems.

The co-authors draw from the Christians et al. (2009) model of four normative democratic roles for journalism in their search for answers. While they critique the limited effectiveness of the traditional monitoring and the watchdog function of the media (and institutional biases of 'objectivity'), they propose the facilitative role seeking to improve the quality of public life and the radical role foregrounding social injustice and abuses of power as being more helpful for climate crisis strategies. They give less emphasis to the collaborative role 'in support for broader and dominant 
social purposes', but this latter category is important in many developing countries, such as in the Pacific.

Their concluding and positive message is that global media reformers and environmentalists have a strong basis for common ground in seeking public support for alternative media and independent journalism as key pillars of democracy and climate communication.

\section{References}

Abadi, M. (2017, September 15). Trump did a 180 on Harvey and Irma after he was asked about climate change, Business Insider Australia. Retrieved from www.businessinsider.com.au/ trump-response-to-hurricane-harveyand-irma-climate-change-2017-9?r

Caputo, M. (2017, September 14). Florida governor remains unsure about climate change after Hurricane Irma. Politico. com. Retrieved from www.politico.com/ states/florida/story/2017/09/14/floridagovernor-remains-unsure-about-climatechange-after-hurricane-irma-114498

Christians, C., Glasser, T., McQuail, D., Nordenstreng, K., and White, R.A. (2009). Normative theories of the media: Journalism in democratic societies. Urbana and Chicago, IL: University of Illinois Press.

Hackett, R. A. (2017). Can peace journalism be transposed to climate crisis news? Pacific Journalism Review, 23(1), 14-24. DOI: http://dx.doi.org/10.24135/ pjr.v23i1.100

McChesney, R.W., \& Nichols, J. (2010). The death and the life of American journalism. Philadelphia, PA: Nation Books.

Multiple authors (2017, September 12). Media reaction: Hurricane Irma and climate change. Carbon Brief. Retrieved from www.carbonbrief.org/mediareaction-hurricane-irma-climate-change

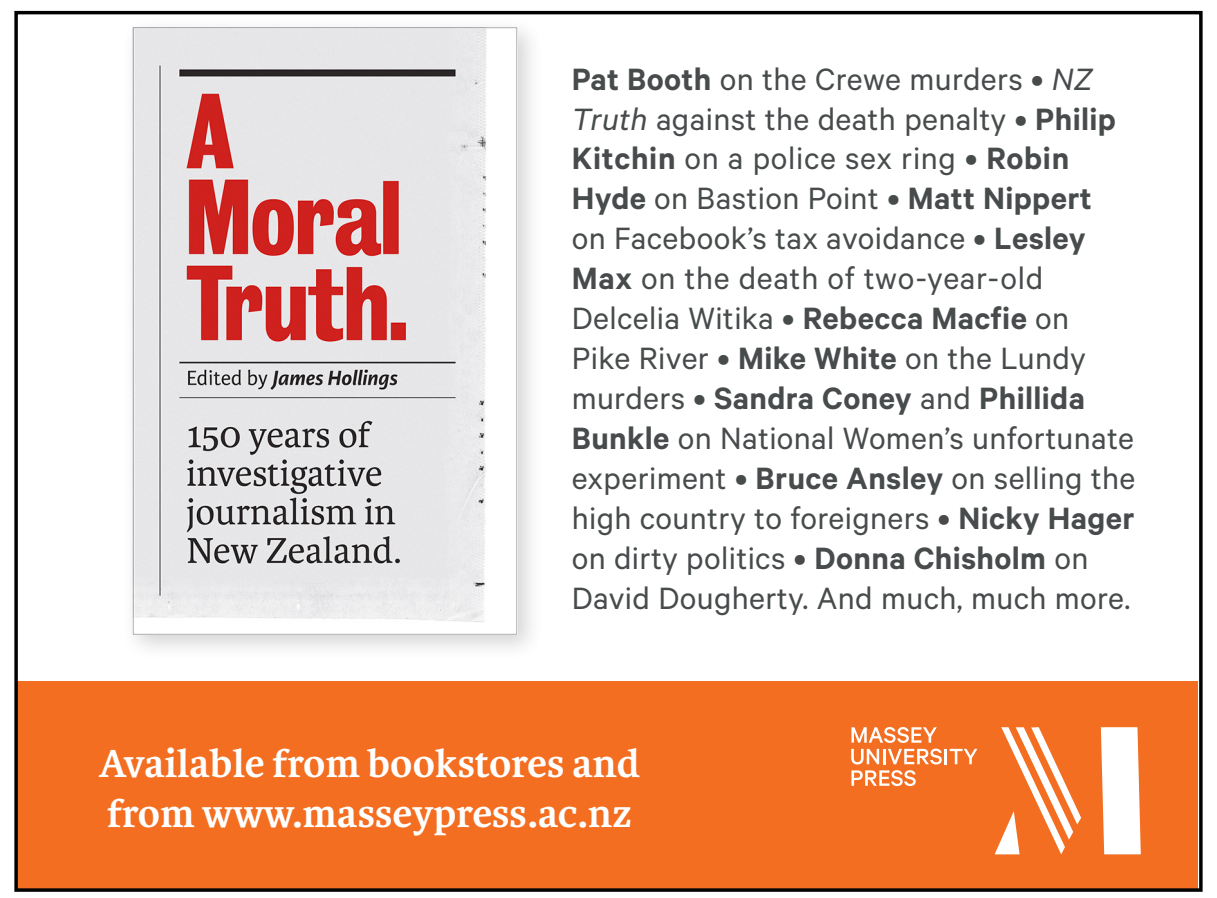

